\title{
STRESS-STRAIN RELATION FOR CONCRETE IN NONUNIFORM TENSION
}

\author{
Michael L. Zak \\ Ariel University, Ariel, ISRAEL
}

\begin{abstract}
Discrepancy between reported in the literature tensile stress-strain relations for concrete is addressed. A conclusion is reached that in the post-peak (softening) range of deformation the stress-strain relation is not unique and depends on the gradient of stress. A simplified variant of such a relation, intended for analysis of concrete beams with regard to the effect of size (the depth of section), is proposed.
\end{abstract}

Keywords: concrete, stress-strain relation, tension, size effect

\section{СООТНОШЕНИЕ «НАПРЯЖЕНИЯ-ДЕФОРМАЦИИ» ДЛЯ БЕТОНА ПРИ НЕОДНОРОДНОМ РАСТЯЖЕНИИ}

\author{
М.Л. Зак \\ Университет Ариэль, г. Ариэль, ИЗРАИЛЬ
}

\begin{abstract}
Аннотация: Рассмотрено несоответствие между приводимыми в литературе соотношениями «напряжения-деформации» для бетона. Делается вывод, что в постпиковом (смягчающем) диапазоне деформирования соотношение «напряжения-деформации» не является единственным и зависит от градиента напряжения. Предложен упрощенный вариант такого соотношения, предназначенный для анализа бетонных балок с учетом размерного эффекта (глубины сечения).
\end{abstract}

Ключевые слова: бетон, соотношение «напряжения-деформации», растяжение, размерный эффект

\section{INTRODUCTION}

The tensile stress $(\sigma)$-strain $(\varepsilon)$ relation is one of principal characteristics of concrete behavior. Unfortunately, there is a considerable uncertainty with regard to the choice of its appropriate variant for nonlinear analysis of concrete and reinforced concrete structures. In particular, (a) reported in the literature (e.g. [15]) relations differ essentially from each other (see Figure 1), and (b) in deformation-controlled direct tension tests on standard concrete specimens the deformation localizes when the ultimate load is attained and, therefore, the descending branches of diagrams, like those in Figure 1, are unrealizable (see $[6,7]$ ).

The aim of this paper is to consider this issue and formulate a new $\sigma-\varepsilon$ relation for concrete in tension. The paper is organized as follows. Firstly, a ratio $m=f_{t, f l, 15} / f_{t}$ is shown to be a

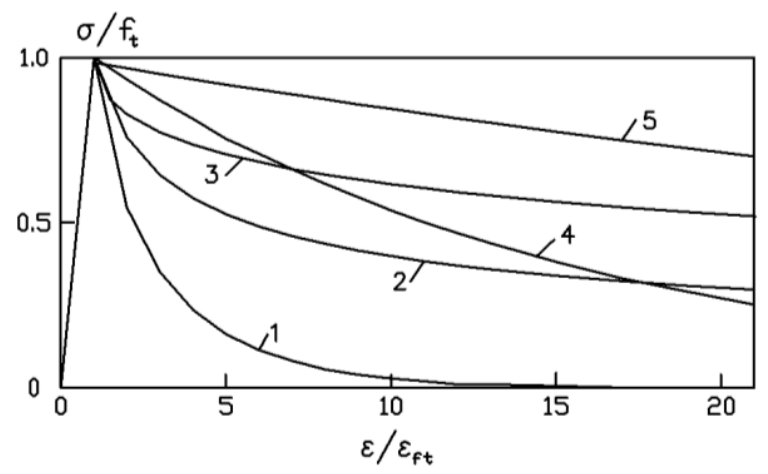

Figure 1. Tensile $\sigma$ - $\varepsilon$ diagrams for concrete: $1-[1], 2-[2], 3-[3], 4-[4], 5-[5]$.

suitable calibration parameter. Here, $f_{t}=$ the strength of concrete in direct tension, $f_{t, f l, 15}=$ the flexural tensile strength of concrete determined 
in tests on standard $15 \times 15 \times 60 \mathrm{~cm}$ concrete beams with the third-point loading. Then, a calibrated relation is presented and an example given illustrating the accuracy of results obtainable with the use of this relation in analysis of relatively small elements. Finally, an extended version of the same relation, intended for analysis of bending elements of any depth, is proposed and its applicability range discussed.

The compressive $\sigma-\varepsilon$ relation [8]

$$
\frac{\sigma}{f_{c}}=\frac{k\left(\varepsilon / \varepsilon_{f c}\right)-\left(\varepsilon / \varepsilon_{f c}\right)^{2}}{1+(k-2)\left(\varepsilon / \varepsilon_{f c}\right)}
$$

where $f_{c}$ is the concrete compressive strength, $\varepsilon_{f c}$ is the strain corresponding to $f_{c}, k=E_{c 0} \varepsilon_{f c} / f_{c}, E_{c 0}$ is the tangent modulus of elasticity at the origin of the $\sigma-\varepsilon$ diagram, and a conventional plane sections hypothesis are adopted in this work for analysis of concrete elements acted upon by the bending moment, $M$, and longitudinal load, $P$, applied at $x=x_{p}$, using the equilibrium equations

$$
b \int_{0}^{d} \sigma(\varepsilon) x d x=M+P x_{p}, \quad b \int_{0}^{d} \sigma(\varepsilon) d x=P .
$$

Here $b, d$ are the width and depth of section, respectively.

\section{COMPARISON OF DIAGRAMS IN FIGURE 1}

See Figure 2.

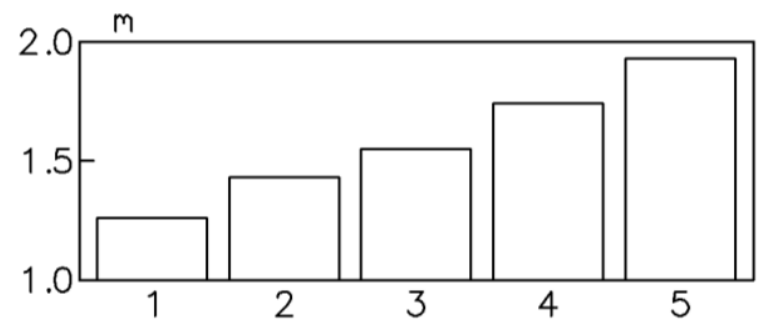

Figure 2. $m$-ratios for concrete of grade $C 30$ $[8]\left(f_{c}=2.9 \mathrm{MPa}, E_{c 0}=33.6 \mathrm{GPa}, \varepsilon_{f_{c}}=2.04 f_{c} / E_{c 0}\right)$ according to diagrams in Figure 1.

\section{PROPOSED RELATION}

The tensile $\sigma-\varepsilon$ relation for concrete is taken in the form similar to that adopted in [9]

$$
\begin{aligned}
& \sigma=E_{c 0} \varepsilon \text { if } \varepsilon \leq \varepsilon_{f t}=f_{t} / E_{c 0}, \\
& \sigma=f_{t} \frac{\gamma\left(\varepsilon / \varepsilon_{f t}\right)}{1+(\gamma-1)\left(\varepsilon / \varepsilon_{f t}\right)^{\gamma /(\gamma-1)}} \quad \text { if } \varepsilon>\varepsilon_{f t} .
\end{aligned}
$$

Here $\gamma=\gamma_{15}$ is a parameter indicating steepness of the descending branch of the diagram (see Figure 3) and obtainable, as a function of the $m$ ratio, from a graph in Figure 4.

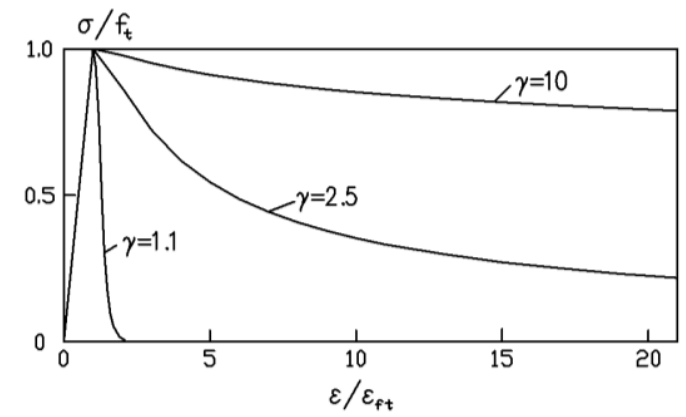

Figure 3. Proposed diagram depending on $\gamma$.

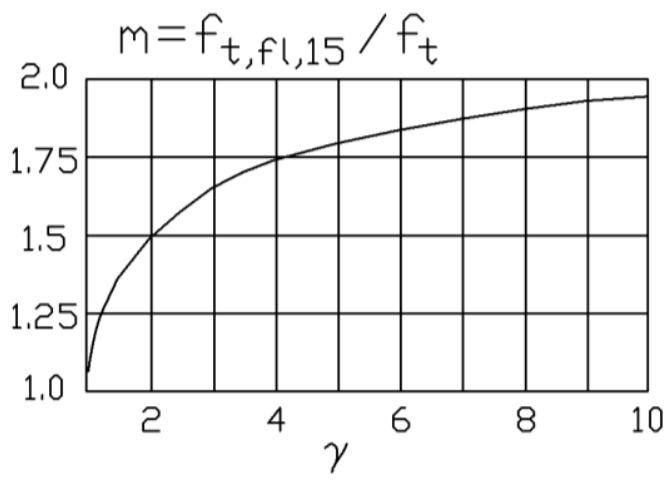

Figure 4. $m$ versus $\gamma=\gamma_{15}$.

In absence of experimental values of $f_{t, f l, 15}$ and $f_{t}$, this ratio can be assessed as follows

$$
\begin{aligned}
& m=2.17-0.02 f_{c}[\mathrm{MPa}] \text { for } f_{c} \leq 25.5 \mathrm{MPa}, \\
& m=1.66 \text { for } f_{c}>25.5 \mathrm{MPa} .
\end{aligned}
$$

See Figure 5. 


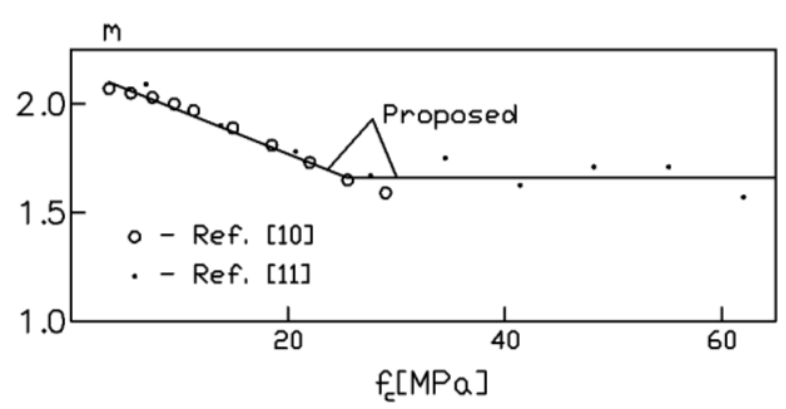

Figure 5. $m$ versus $f_{c}$.

Values of $f_{t, f l, 15}$ and $m$ for standard concrete beams tested with the third-point loading are lower than the corresponding values, $f_{t, f l, 15}^{C P}$ and $m^{C P}$, for identical beams tested with the centerpoint loading. According to [11], $m=m^{C P} / 1.09$.

\section{EXAMPLE}

In tests [12], shown schematically in Figure 6,
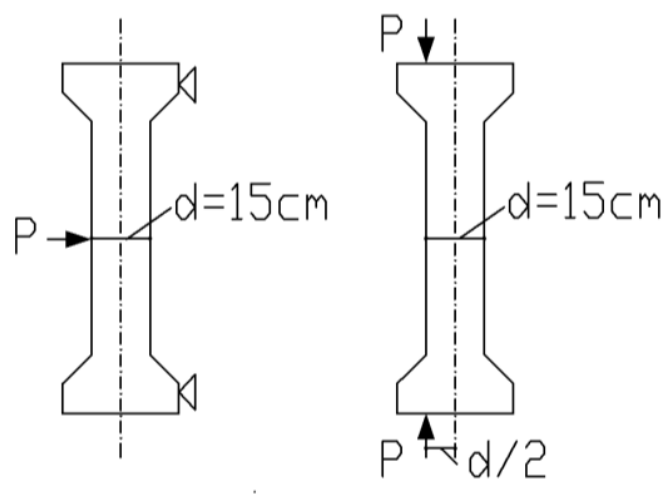

Figure 6. Schemes of tests [12].

the following data have been obtained: $f_{\text {cube }}=350 \mathrm{kgf} / \mathrm{cm}^{2}, f_{t}=15.2 \mathrm{kgf} / \mathrm{cm}^{2}, m^{C P}=1.9$, $P_{u l t}^{\exp }=3.19 P_{0}$, where $P_{0}=f_{t} b d$. Here $P_{u l t}^{\exp }$ is the mean experimental value of ultimate loads for eccentrically loaded plain concrete specimens. From the graph in Figure 4, $\gamma=4.0$ for $m=m^{C P} / 1.09=1.74 . f_{c} \approx 0.8 f_{\text {cube }}, k \approx 2.1$. The calculated ultimate load $P_{u l t}^{\text {num }}=3.08 P_{0}$ deviates from $P_{u l t}^{\text {exp }}$ by $3.4 \%$. Note that shrinkage of the concrete in the considered tests [12] was prevented.

\section{PROPOSED RELATION: EXTENDED VERSION}

When the concrete shrinkage is prevented, $f_{t}$ is practically independent of the specimen's crosssectional dimensions. See Appendix and Ref. [12]. Unlike $f_{t}$, the concrete flexural tensile strength $f_{t, f l}=6 M_{u l t} /\left(b d^{2}\right)$, where $M_{u l t}$ is the ultimate bending moment for a plain concrete beam of rectangular $(b \times d)$ section, depends essentially on $d$. In order to reflect this size effect, parameter $\gamma$ in the proposed relation is taken as a function of $d$

$\gamma=\gamma_{15}$ if $10 \leq d \leq 20 \mathrm{~cm}$,

$\gamma=\max \left[1.01 ; 1+\left(\gamma_{15}-1\right) 0.1^{\alpha}\right]$ if $d>20 \mathrm{~cm}$,

where $\alpha=(d[\mathrm{~cm}]-20) / 30$. See Figure 7 .

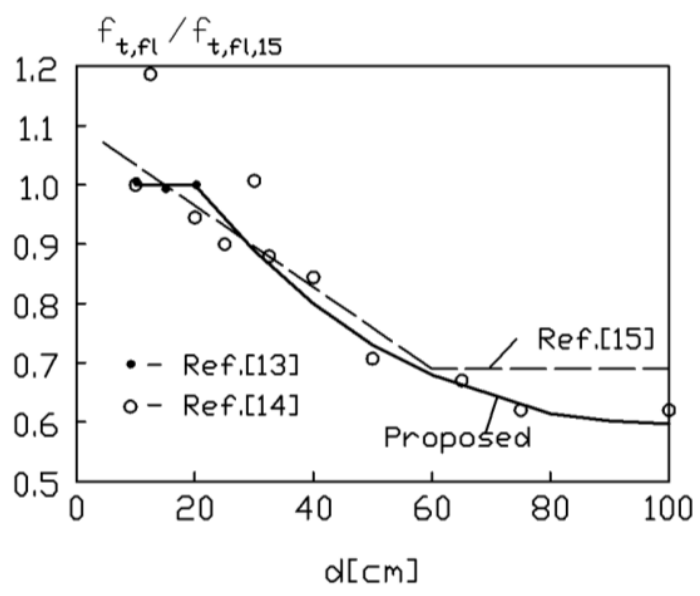

Figure 7. $f_{t, f l} / f_{t, f l, 15}$ versus $d$.

\section{DISCUSSION}

Irrespective of the cross-sectional dimensions, the behavior of concrete in uniform tension is similar to that in flexural tension when $d \rightarrow \infty$. Therefore, the shape of the tensile $\sigma-\varepsilon$ diagram depends on the stress gradient. In the proposed simplified relation, intended for analyses of bending elements, this dependence is taken into account implicitly. 


\section{CONCLUSIONS}

1. A new $\sigma-\varepsilon$ relation for tensile concrete is proposed.

2. The proposed relation models ductile and brittle modes of the concrete behavior in shallow and deep bending elements, respectively.

3. Based on tests of relatively small laboratory specimens, empirical formulas, like that in Ref. [16] for reinforced concrete beams' deflections, may be unsafe in application to large elements.

\section{APPENDIX}

Figure 8 presents the averaged data obtained in direct tension tests [17] on concrete specimens with dimensions of the working parts $10 \times 10 \times 30$, $20 \times 20 \times 70$ and $50 \times 50 \times 110 \mathrm{~cm}$. In series 1 of the tests, the specimens were sealed in order to prevent shrinkage of the concrete. In series 2, the specimens were not sealed. It is seen that sealing the specimens reduces the size effect to the level predicted by the "weakest link" theory (e.g. [18])

$$
\frac{f_{t}(L)}{f_{t}\left(L_{0}\right)}=1-v \sqrt{\ln \left(\frac{L}{L_{0}}\right)},
$$

where $f_{t}(L)$ is the strength of specimen of length $L, L_{0}=30 \mathrm{~cm}, v$ is the variability of $f_{t}\left(L_{0}\right)$ assumed to be in the interval $(0.05,0.1)$.

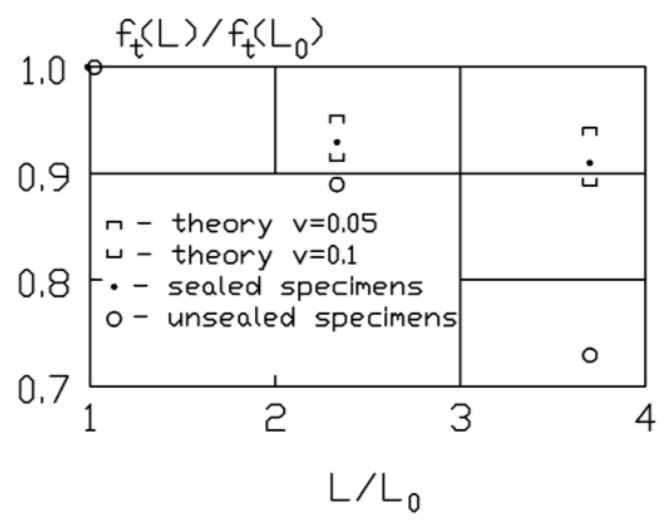

Figure 8. $f_{t}(L) / f_{t}\left(L_{0}\right)$ versus $L / L_{0}$.
It can be concluded, therefore, that - when shrinkage of the concrete is prevented $-f_{t}$ depends moderately on $L$, but is practically independent of the cross-sectional dimensions.

\section{REFERENCES}

1. Dere Y., Koroglu M.A. Nonlinear FE Modeling of Reinforced Concrete. // International Journal of Structural and Civil Engineering Research, 2017, Volume 6, No. 1, pp. 71-74.

2. Hsu T.T., Zhang S.J. Tension Stiffening in Reinforced Concrete Membrane Elements. // ACI Structural Journal, 1996, Volume 93, No. 1, pp. 108-115.

3. Bentz E.C., Veccio F.J., Collins M.P. Simplified Modified Compression Field Theory for Calculating Shear Strength of Reinforced Concrete Elements. // ACI Structural Journal, 2006, Volume 103, No. 4, pp. 614-624.

4. Fields K., Bischoff P. Tension-Stiffening and Cracking of High-Strength Reinforced Concrete Tension Members. // ACI Structural Journal, 2014, Volume 101, No.4, pp. 447-456.

5. Stramandinoli R.S.B., Rovere H.L. An Efficient Tension-Stiffening Model for Nonlinear Analysis of Reinforced Concrete Members. // Engineering Structures, 2008, Volume 30, No.7, pp. 2069-2080.

6. Reinhardt H.W. Factors Influencing the Tensile Properties of Concrete. In "Understanding the Tensile Properties of Concrete", Ed. J. Weerheim, Oxford, 2013, pp. 19-51.

7. Zak M.L. On Modeling of Concrete Behavior in Post-Peak Range of Deformation. In "The Optimization of the Composition, Structure and Properties of Metals, Oxides, Composites, Nano- and Amorphous Materials", Proc. of the Sixteenth Bi-National Workshop Russia- 
Israel, Ariel University, Ariel, 28-31 August 2017, pp. 237-246.

8. Model Code 2010. Final Draft. Vol. 1. fib Bull. No. 65, 2012, 311 pages.

9. Prakhya G.K.V., Morley C.T. TensionStiffening and Moment-Curvature Relations of Reinforced Concrete Elements. // ACI Structural Journal, 1990, Volume 87, No.5, pp. 597-605.

10. ACI Committee 224. Cracking of Concrete in Direct Tension, 1997, 12 pages.

11. Heilmann H.G. Beziehungen zwischen Zug- und Druckfestigkeit de Betons. // Beton, 1969, No. 2, pp. 68-70.

12. Mal'cov K.A. Fizicheskoe znachenie predela prochnosti betona na razryv pri izgibe [Physical Significance of Flexural Tensile Strength of Concrete]. // Beton $i$ Zhelezobeton, 1958, No. 3, pp. 107-111 (in Russian).

13. Nielsen K.E.C. Effect of Various Factors on the Flexural Strength of Concrete Test Beams. // Magazine of Concrete Research, 1954, No. 3, pp. 105-114.

14. Mal'cov K., Karavaev A. "Abhangigkeit der Festigkeit des Betons auf Zug bei Biegung und aussmittiger Belastung von den Querschnittsabmessungen", Wiss. Z. Univers. Dresden, Vol. 17, H. 6, 1968, pp. 1545-1547.

15. Eurocode 2: Design of Concrete Structures - Part 1-1: General Rules and Rules for Buildings, Brussels, 2014, 225 pages.

16. ACI Committee 318. Building Code Requirements for Structural Concrete (ACI 318-14) and Commentary (ACI 318R-14), American Concrete Institute, Farmington Hills, MI, 2014, 503 pages.

17. Vorob'eva V.I., Simakov G.K., Sudakov V.B. Masshtabnyj faktor pri ispytanii obrazcov na osevoe rastjazhenie [Scale Factor in Direct Tensile Tests]. In "Effect of Concrete Properties on Its Cracking Strength". Works of Coordination Meetings on Hydraulic Structures, 1976, No. 112, Leningrad, pp. 154-161 (in Russian).
18. Bolotin V.V. Statistical Methods in Structural Mechanics. Holden-Day, 1969, $240 \mathrm{pp}$.

\section{СПИСОК ЛИТЕРАТУРЫ}

1. Dere Y., Koroglu M.A. Nonlinear FE Modeling of Reinforced Concrete. // International Journal of Structural and Civil Engineering Research, 2017, Volume 6, No. 1, pp. 71-74.

2. Hsu T.T., Zhang S.J. Tension Stiffening in Reinforced Concrete Membrane Elements. // ACI Structural Journal, 1996, Volume 93, No. 1, pp. 108-115.

3. Bentz E.C., Veccio F.J., Collins M.P. Simplified Modified Compression Field Theory for Calculating Shear Strength of Reinforced Concrete Elements. // ACI Structural Journal, 2006, Volume 103, No. 4, pp. 614-624.

4. Fields K., Bischoff P. Tension-Stiffening and Cracking of High-Strength Reinforced Concrete Tension Members. // ACI Structural Journal, 2014, Volume 101, No.4, pp. 447-456.

5. Stramandinoli R.S.B., Rovere H.L. An Efficient Tension-Stiffening Model for Nonlinear Analysis of Reinforced Concrete Members. // Engineering Structures, 2008, Volume 30, No.7, pp. 2069-2080.

6. Reinhardt H.W. Factors Influencing the Tensile Properties of Concrete. In "Understanding the Tensile Properties of Concrete", Ed. J. Weerheim, Oxford, 2013, pp. 19-51.

7. Zak M.L. On Modeling of Concrete Behavior in Post-Peak Range of Deformation. In "The Optimization of the Composition, Structure and Properties of Metals, Oxides, Composites, Nano- and Amorphous Materials", Proc. of the Sixteenth Bi-National Workshop RussiaIsrael, Ariel University, Ariel, 28-31 August 2017, pp. 237-246. 
8. Model Code 2010. Final Draft. Vol. 1. fib Bull. No. 65, 2012, 311 pages.

9. Prakhya G.K.V., Morley C.T. TensionStiffening and Moment-Curvature Relations of Reinforced Concrete Elements. // ACI Structural Journal, 1990, Volume 87, No.5, pp. 597-605.

10. ACI Committee 224. Cracking of Concrete in Direct Tension, 1997, 12 pages.

11. Heilmann H.G. Beziehungen zwischen Zug- und Druckfestigkeit de Betons. // Beton, 1969, No. 2, pp. 68-70.

12. Мальков К.А. Физическое значение предела прочности бетона на разрыв при изгибе. // Бетон и железобетон, №3, 1958 , c. 107-111.

13. Nielsen K.E.C. Effect of Various Factors on the Flexural Strength of Concrete Test Beams. // Magazine of Concrete Research, 1954, No. 3, pp. 105-114.

14. Mal'cov K., Karavaev A. "Abhangigkeit der Festigkeit des Betons auf Zug bei Biegung und aussmittiger Belastung von den Querschnittsabmessungen", Wiss. Z. Univers. Dresden, Vol. 17, H. 6, 1968, pp. 1545-1547.

15. Eurocode 2: Design of Concrete Structures - Part 1-1: General Rules and Rules for Buildings, Brussels, 2014, 225 pages.

16. ACI Committee 318. Building Code Requirements for Structural Concrete (ACI 318-14) and Commentary (ACI 318R-14), American Concrete Institute, Farmington Hills, MI, 2014, 503 pages.

17. Воробьева В.И., Симаков Г.К., Судаков В.Б. Масштабный фактор при испытании образцов на осевое растяжение. // Труды координационного совещания по гидротехническим сооружениям, 1976, Выпуск 112, с. 154157.

18. Bolotin V.V. Statistical Methods in Structural Mechanics. Holden-Day, 1969, 240 pages.

Michael L. Zak, PhD, Lecturer, Civil Engineering Department, Ariel University, Ariel 40700, Israel,
E-mail:m.1.zak@012.net.il

Майкл Л. Зак, доктор наук (PhD), Университет Ариэль; Ариэль 40700, Израиль;

E-mail: m.1.zak@012.net.il. 